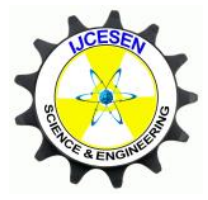

Copyright C IJCESEN
International Journal of Computational and

Experimental Science and Engineering

(IJCESEN)

Vol. 3-No.1 (2017)pp.1-6

http://iakkurt.dergipark.gov.tr/ijcesen

ResearchArticle

\title{
Separation of Copper and Zinc from aqueous solution using Liquid- Membrane-Gel (LMG) containing Trioctylphosphine Oxide TOPO as Carrier\#
}

\author{
Nadjet TAOUALIT $^{1 *}$, Ismail ABIDAT ${ }^{2}$, Djamal-Eddine HADJ-BOUSSAAD ${ }^{1}$ \\ ${ }^{1}$ Laboratoire des appliquations énergétiques de l'hydrogène, Saad-Dahlab Üniversity, Techology Faculty, Process \\ Engineering Department, 09000, Blida-Algeria \\ ${ }^{2}$ Saad-Dahlab Üniversity, Techology Faculty, Process Engineering Department, 09000, Blida-Algeria \\ * Corresponding Author : ntaoualit@ hotmail.fr
}

(First received 25 November 2016 and in final form 20 February 2017)

\# Presented in " $3^{\text {rd }}$ International Conference on Computational and Experimental Science and Engineering (ICCESEN-2016)"

Keywords

Liquid-membrane-gel

Copper

TOPO

Zinc

\begin{abstract}
Transfer and extraction of metallic species $\left(\mathrm{Ag}^{+}\right.$and $\mathrm{Cu}^{2+}$ ions) through a flat sheet dense supported-liquid-membrane was investigated previously $[1,2]$ using thin sheets of polybutadiene rubber cross-linked with $0.1 \%$ and/or $0.4 \%$ of dicumylperoxyde at $160^{\circ} \mathrm{C}$ for 15 minutes noted $\mathrm{BR}_{1}$ and for 5 minutes noted $\mathrm{BR}_{2}$ [3]. In this work, column filled with a liquid-membrane-gel LMG in form of beads impregnated beforehand with the solvating organo-phosphoric carrier the trioctyl phosphine oxide TOPO, was used to study the extraction-concentration-recovery and the transport of $\mathrm{Cu}$ (II) and $\mathrm{Zn}$ (II) from an aqueous solution. Extraction of $\mathrm{Cu}$ (II) at different $\mathrm{pH}$ aqueous solutions has been described. The speciation of the extracted complexes in the membrane supported organic phase (extractant) was also, performed using the theoretically derived equations to elucidate the stoichiometry and the $\mathrm{Cu}$ (II) mechanism complexation through the liquid-membrane-gel LMG. Kinetic parameters were calculated from the experimental data. About $86-97 \%$ and $50-82 \%$ of respectively copper and zinc, were extracted from aqueous solutions at $\mathrm{pH}=6$ according to first-order kinetics and the separation factor away from the unit. The solvated copper species by TOPO are of the type $\left[\mathrm{Cu}\left(\mathrm{NO}_{3}\right)_{2}\right] \mathrm{TOPO}$.
\end{abstract}

\section{Introduction}

World Health Organization (W.H.O) has recommended a daily intake of copper $30 \mu \mathrm{g} . \mathrm{kg}^{-1}$ body weight per day (or $2.1 \mathrm{mg}$. day ${ }^{-1}$ ) in the case of an adult man and $80 \mathrm{mg} . \mathrm{kg}^{-1}$ body weight per day for infants.

These recommendations were based on balance studies among children and adults, including studies of contributions necessary to compensate the daily loss of copper due to metabolism and excretion. The recommendations in the case of adults ( 2 to $3 \mathrm{mg}$ day $^{-1}$ ) are similar to those of the National Academy of Sciences. Inputs it was reported that only $5.3 \mathrm{mg}$. day ${ }^{-1}$ could be slightly toxic, but in most cases reported toxicity, it is question of concentrations of at least $15 \mathrm{mg}$. day ${ }^{-1}$, [4].
According to World Health Organization the metals of most immediate concern are chromium, copper, zinc, iron, mercury and lead [5].

Copper poisoning effects for a long-term are well known: the excess copper in the blood is not readily determinable because the copper is immediately stored in the liver, as cupro proteins. When the excess copper in the blood is measurable, it means that the cupric storage capacities in the liver are saturated. Copper then disturbs the metabolism of iron and causes the liver steatosis and cirrhosis [6]. Different disorders have been described as a consequence of the accumulation of copper in animals and humans.

Acute copper poisoning causes severe gastro enteritis characterized by abdominal pain, diarrhea, anorexia, dehydration and shock. Chronic exposure to copper is the cause of Wilson's disease, characterized by hepatic cirrhosis, brain damage, 
demyelination, renal involvement, and copper deposition in the cornea [5].

While, long-term exposure to copper can cause irritation of the nose, mouth and eyes and it causes headaches, stomachaches, dizziness, vomiting and diarrhea. Intentionally high uptakes of copper may cause liver and kidney damage and even death [7]. The discharge of heavy metals, such as copper, zinc..., into the environment is a serious problem facing numerous industries. The search for extraction techniques to remove those heavy metals is of increasing interest. Conventional techniques are either costly or they produce large quantities volumes of wastes.

Liquid membranes have shown great potential in this way, especially in cases where metal concentrations are relatively low and other techniques cannot be applied efficiently.

Liquid membranes technologies have been proposed as a real challenge for the treatment of such solution [8] because they are considered as clean processes that avoid toxic waste in the environment and ensure their recycling.

In the present work, we have involved liquidmembranes-gels (LMGs) which are hydrophobic membranes inflated by specific organic extractants, in order to treat synthetic solutions with the same composition of those of surfaces treatments discharges containing copper and zinc ions.

Polystyrene bead form $[9,10]$ or styrene divinylbenzene polymers [11,12], polyurethanes foams [13-20] and silicone rubber [21], were the first to be used as solid supports on which is fixed the extraction solvent in order to lead (form) organic gels. Therefore, the mobile organic phase in the solvent extraction system is replaced by an immobilized phase in a solid matrix [22].

\section{Experimental}

To prepare the liquid-membrane-gel, several polymeric solid supports in form of beads have been used such as ethylene-vinyl acetate (EVA), polyethylene terephthalate (PET) and polyvinyl chloride (PVC). Firstely, they were swelled in the solvating extractant trioctyl phosphine oxide TOPO (from Fluka) at $0.2 \mathrm{M}$ in respectively chloroform, toluene and carbon tetrachloride (all $>99.5 \%$ from Panreac), these were used as solvents to obtain the organic matrix.

Obtained membrane was immediately placed in a glass column with known dimensions (figure 1) and forming then a bed of a particular height.

This kind of column has been used by Klement [23] in the process of ion exchange to separate and recover metal ions from various types of solutions such as rinse waters of plating shops, or solutions for the photographic industry ... etc...

In through this column (figure 1), $500 \mathrm{~mL}$ of copper solution (from dissolved copper nitrates) of $10 \mathrm{mg}$. $\mathrm{L}^{-1}$ at known $\mathrm{pH}$, percolated. .

Successive samples, according of the time, of the resulting solution (treated) were conducted to be analyzed to determine the concentration of copper ions, using atomic absorption spectrometry at $324.8 \mathrm{~nm}$.

Yield of extraction is the efficiency of the extraction or the rate of extracted solute [24]. It can be calculated according to:

$E(\%)=\frac{C_{\text {org. }} V_{\text {org. }}}{C_{\text {org. } .} V_{\text {org. }}+C_{\text {aq. } .} V_{\text {aq. }}} \times 100$

$V_{a q .}:$ volume of aqueous phase,

$V_{\text {org. }}$ volume organic phase (inside the membrane).

This relation can be written as a function of the distribution coefficient of the solute (extraced metal), we have:

$$
E(\%)=\frac{D}{D+\frac{V_{a q .}}{V_{\text {org. }}}} \times 100
$$

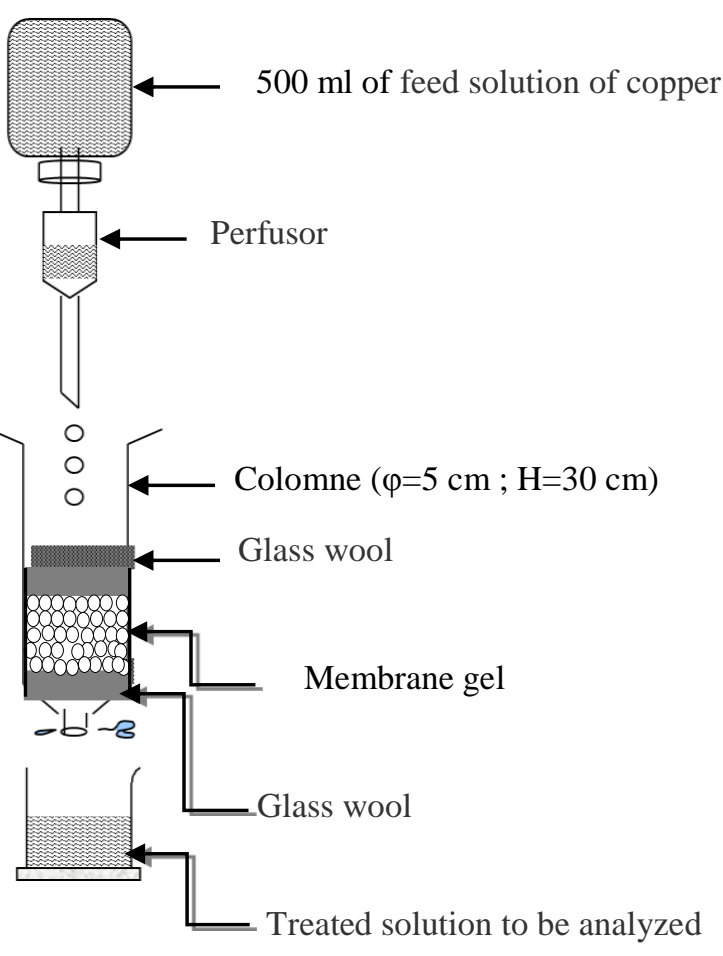

Figure 1. Experimental Device [22]

In the present study, the column system was used to track the kinetic of liquid-membrane-gel extraction of copper and its separation from zinc metal. 
Several parameters influence the efficiency of the extraction such as $\mathrm{pH}$ of the feed solution, extractant concentration and the flow of the percolation...

We have investigated, in the present paper, the $\mathrm{pH}$ effect of feed phase on copper liquid-membraneextraction. The other parameters were subject of other studies. Chosen $\mathrm{pH}$ range was 2, 4, 6 and 8. İt was avoided higher $\mathrm{pH}$ values that cause the precipitation of copper.

The $\mathrm{pH}$ of each phase was adjusted with $\mathrm{HNO}_{3}$ $0.1 \mathrm{~N}$ solution for acidic media and $\mathrm{NaOH} 0.1 \mathrm{~N}$ for basic media and it was measured by a OHAUS pHmeter, equipped with a combined glass electrode.

\section{Results}

\subsection{Influence of $\mathbf{p H}$ of aqueous solution on copper extraction}

$\mathrm{pH}$ is an important parameter infuencing the extraction and the complexation of metallic ions by slovating extractant at the interface. Figure 2 shows the effect of $\mathrm{pH}$ on copper extraction using the three different liquid- membranes-gels.

In view of these results, we note that:

-The increase in $\mathrm{pH}$ favors the extraction of copper. -The best extraction yields (E\%) of extraction are obtained at $\mathrm{pH}=6$ and $\mathrm{pH}=8$.

However, it is important to note that if the $\mathrm{pH}$ increases above 6 , will there be a precipitation of copper at this initial concentration of $10 \mathrm{mg}$. $\mathrm{L}^{-1}$. It becomes quantitative from a $\mathrm{pH}$ of 7.5 according to [25].

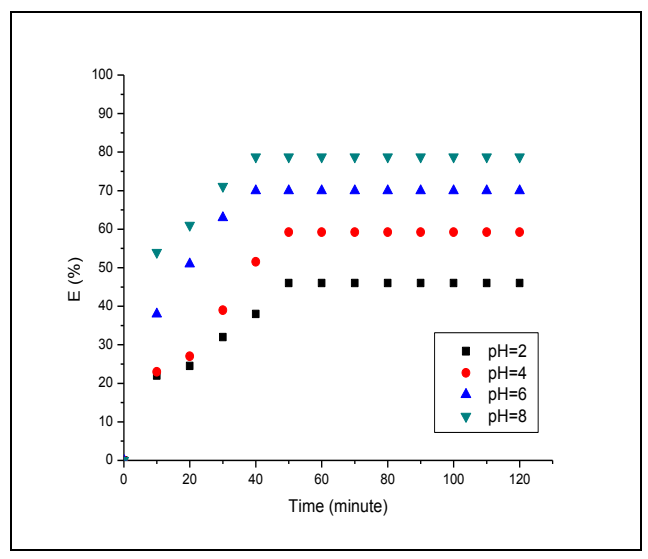

Figure 2. Effect of $p H$ on copper extraction

Therefore, it is interesting to study the extraction of copper firstly at $\mathrm{pH} 6$, and then compare the results to those at $\mathrm{pH} 8$ using the liquid-membranes EVA/TOPO in respectively carbon tetrachloride, Chloroform and Toluene at $0.2 \mathrm{M}$.
Table 1 summarizes obtained yields of copper extraction at $\mathrm{pH} 6$ and $\mathrm{pH} 8$.

From comparaison, the best extraction yields (E\%) at $\mathrm{pH} 8$ are greater than those obtained at $\mathrm{pH} 6$. This is probably due to the precipitation of copper in the feed phase in which the initial concentration of copper in the feed phase has decreased below the under of $10 \mathrm{mg}$. $\mathrm{L}^{-1}$ promoting thus the extraction of the species $\left(\left[\mathrm{Cu}^{2+}\right]_{\text {initial }}<10 \mathrm{mg}\right.$. $\left.\mathrm{L}^{-1}\right)$.

We have chosen so to carry all experiments at $\mathrm{pH} 6$ for the rest of our work.

Table 1. Yields of extraction of Copper at $p H=6$ and $p H=8$

\begin{tabular}{|l|c|c|}
\hline \multicolumn{1}{|c|}{ LMG system } & $\begin{array}{c}\mathrm{E}(\%) \text { at } \\
\mathrm{pH}=6\end{array}$ & $\begin{array}{c}\mathrm{E}(\%) \text { at } \\
\mathrm{pH}=8\end{array}$ \\
\hline EVA/TOPO/ carbon tetrachloride & 87.3 & 91.5 \\
\hline EVA/TOPO/Chloroform & 71.3 & 75 \\
\hline EVA/TOPO/Toluene & 70 & 78.65 \\
\hline
\end{tabular}

\subsection{Liquid-Membrane-Extraction of copper}

a) The same experimental device was used in this section of our work in order to study the concentration-extraction and recovery of copper using the different liquid-membranes-gels containing TOPO as carrier in the presence of the precedent solvents.

Obtained results show that 30-50 minutes are sufficient to reach fast kinetic equilibrium. About 60 to $99 \%$ of copper were extracted with concentration factors about 21 to 310 times (for exemple figure 3 ).

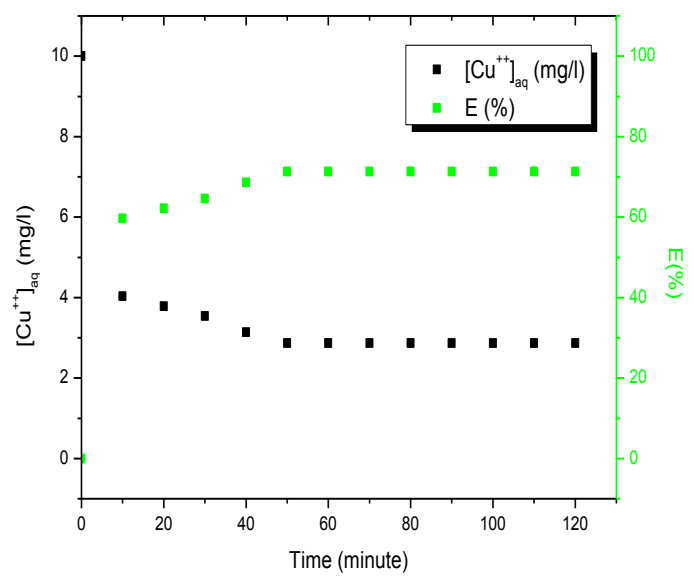

Figure 3. Kinetic and yield extraction of Copper alone by EVA/TOPO/Chloroform

b) the second part of this paragraphe concerns the co- extraction of copper and zinc. The feed aquous solution was so a mixture of copper and zinc equimolar to10 mg. $\mathrm{L}^{-1}$. 
Samples of the treated solution (figure 1) were analyzed according to time to determine the concentration of copper and zinc ions successively using atomic absorption spectrometry at $324.8 \mathrm{~nm}$ and $219.3 \mathrm{~nm}$ respectively.

Results show that copper ions were extracted in the presence of zinc by the liquid-membranes-gels with the similar yields as those obtained in the case of copper ions alone, (Figure 3). They are of the order of 86-97 \%, but those of zinc ions range from 50-82 $\%$, (Figure 6).

The extraction of $\mathrm{Cu}^{2+}$ ions is greater than that of $\mathrm{Zn}^{2+}$ ions. Equilibrium was reached at about 40 minutes for copper (figure 4) and about 80 minutes (figure 5) for zinc.

The factors of concentration of $\mathrm{Cu}^{2+}$ are not different, in the presence of $\mathrm{Zn}^{2+}$. This presents an interesting possibility for the concentration and separation of metals from a mixture of metallic species.

$\mathrm{Cu}^{2+}$ ions factor of separation over $\mathrm{Zn}^{2+}$ ions away from the unit.

\section{Modeling}

Obtained experimental results were modeled according to two models that we present as follows: the first order model and the second order model. Obtained kinetic data are summarized in Table 2.

Examination of these results shows that the kinetics of copper extraction using the 08 different liquidmembranes-gels systems are well described by the first order kinetic model with satisfactory correlation coefficients $\left(\mathrm{R}^{2}>\quad 0.96\right)$.

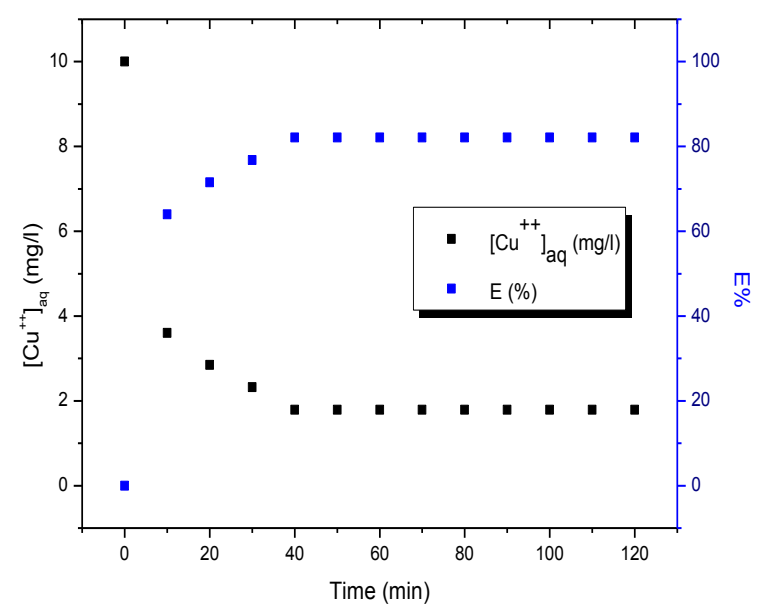

Figure 4. Kinetic and yield extraction of Copper by EVA/TOPO/Chloroform LMG in presence of Zinc

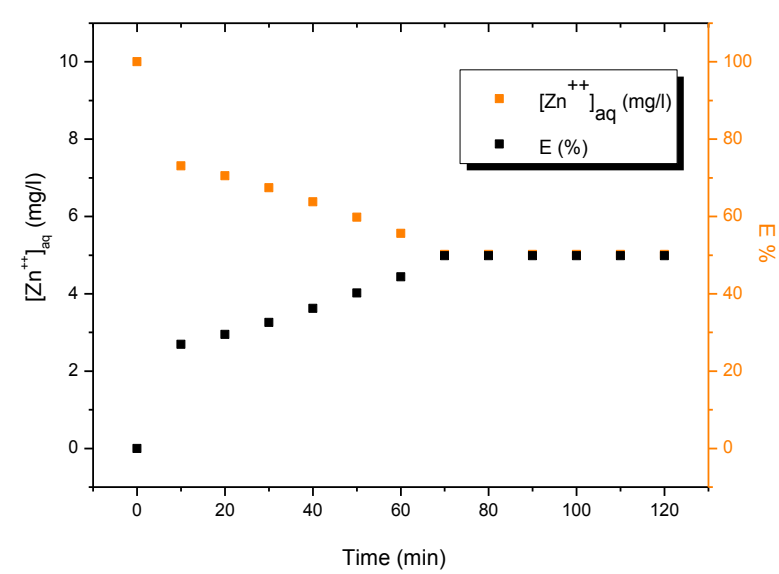

Figure 5. Kinetic and yield extraction of Zinc by EVA/TOPO/Chloroform LMG

\section{Extracted Complexes Nature}

The extraction of copper ions by solvatation (neutral extractant TOPO), is produced according to the following mechanism:

$$
\mathrm{Cu}^{2+}+2 \mathrm{NO}_{3}^{-}+\mathrm{eTOPO} \leftrightarrow \overline{\mathrm{Cu}\left(\mathrm{NO}_{3}\right)_{2} \mathrm{TOPO}_{\mathrm{e}}}
$$

The following relation gives the constant of this equilibrium:

$$
\mathrm{K}_{\mathrm{ext} .}=\frac{\left[\overline{\overline{\mathrm{Cu}\left(\mathrm{NO}_{3}\right)_{2} \mathrm{TOPO}_{\mathrm{e}}}}\right]}{\left[\mathrm{Cu}^{2+}\right] \mathrm{x}\left[\mathrm{NO}_{3}^{-}\right]^{2} \mathrm{x}[\overline{\mathrm{TOPO}}]^{\mathrm{e}}}
$$

The distribution coefficient, in logarithmic form, is: $\log \mathrm{D}_{\mathrm{Cu}}=\log \mathrm{K}_{\mathrm{e}}+2 \log \left[\mathrm{NO}_{3}^{-}\right]+\operatorname{elog}[\overline{\mathrm{TOPO}}]$

If we take account of the successive equilibriums:

$$
\mathrm{Cu}^{2+}+2 \mathrm{NO}_{3}^{-} \leftrightarrow \mathrm{Cu}\left(\mathrm{NO}_{3}\right)_{2}
$$

With the constant $\beta_{\left(\mathrm{NO}_{3}\right)}$, then, the distribution coefficient in the logarithmic form can be written as following:

$$
\begin{gathered}
\log \mathrm{D}_{\mathrm{Cu}}=\log \mathrm{K}_{\mathrm{e}}+2 \log \left[\mathrm{NO}_{3}^{-}\right]+\mathrm{e} \log [\overline{\mathrm{TOPO}}]- \\
\log \left[1+\sum \beta_{\left(\mathrm{NO}_{3}\right)}\left[\mathrm{NO}_{3}^{-}\right]^{2}\right]
\end{gathered}
$$

The equation of $\log \mathrm{D}_{\mathrm{Cu}}$ allows constructing the curve $\log \mathrm{D}_{\mathrm{Cu}}=\mathrm{f}(\log [\mathrm{TOPO}])$ and therefore, gets the coefficient $\boldsymbol{e}$, slope of the straight.

Variation of $\log D_{C u}=f(\log [\overline{T O P O}])$

The aqueous phases are composed of copper of $10 \mathrm{mg} . \mathrm{l}^{-1}$ prepared from copper nitrates. 
Table 2. Kinetic constants of copper extraction by the prepared liquid-membranes-gels, according to the first and second order models

\begin{tabular}{|c|c|c|c|c|}
\hline \multirow{2}{*}{$\begin{array}{c}\text { Liquid- } \\
\text { membrane-gel }\end{array}$} & \multicolumn{2}{|c|}{$\begin{array}{c}\text { First order } \\
\text { model }\end{array}$} & \multicolumn{2}{|c|}{$\begin{array}{c}\text { Second order } \\
\text { model }\end{array}$} \\
\hline & $\begin{array}{c}\mathrm{K}_{1} \\
\left(\min ^{-1}\right)\end{array}$ & $\mathrm{R}^{2}$ & $\begin{array}{c}\mathrm{K}_{2} \\
\left(\min ^{-1}\right)\end{array}$ & $\mathrm{R}^{2}$ \\
\hline $\begin{array}{l}\text { EVA/TOPO/ } \\
\text { Chloroform }\end{array}$ & 0.168 & 0.981 & 0.375 & 0.875 \\
\hline $\begin{array}{l}\mathrm{PVC} / \mathrm{TOPO} / \\
\text { Chloroform }\end{array}$ & 0.129 & 0.982 & 0.265 & 0.899 \\
\hline $\begin{array}{l}\text { PET/TOPO/ } \\
\text { Chloroform }\end{array}$ & 0.107 & 0.972 & 0.191 & 0.940 \\
\hline $\begin{array}{l}\text { EVA/TOPO/ } \\
\text { Toluene }\end{array}$ & 0.177 & 0.993 & 0.456 & 0.939 \\
\hline $\begin{array}{l}\mathrm{PVC} / \mathrm{TOPO} / \\
\text { Toluene }\end{array}$ & 0.176 & 0.995 & 0.458 & 0.948 \\
\hline $\begin{array}{l}\mathrm{PET} / \mathrm{TOPO} / \\
\text { Toluene }\end{array}$ & 0.113 & 0.987 & 0.213 & 0.878 \\
\hline $\begin{array}{l}\text { EVA/TOPO/Carb } \\
\text { on Tetrachloride }\end{array}$ & 0.160 & 0.988 & 0.373 & 0.908 \\
\hline $\begin{array}{l}\text { PET/TOPO/Carbo } \\
\text { n Tetrachloride }\end{array}$ & 0.161 & 0.975 & 0.338 & 0.840 \\
\hline
\end{tabular}

The organic phases are obtained by swelling the polymeric support of EVA and PET in a solution of the extractant (TOPO) diluted in Carbon Tetrachloride.

Once the membranes-gels obtained, they were placed in the same column used previously (figure 1) through which the aqueous solution of copper percolated.

Obtained results (Figure 6) show that the slope is near one, the extracted complex is so of the type $\overline{\left[\mathrm{Cu}\left(\mathrm{NO}_{3}\right)_{2}\right] \mathrm{TOPO} \text {. }}$

This result is in perfect agreement with the other works relative to the extraction and the facilitated transport of the metals or organic compounds through liquid membranes containing solvating carrier [26-30].

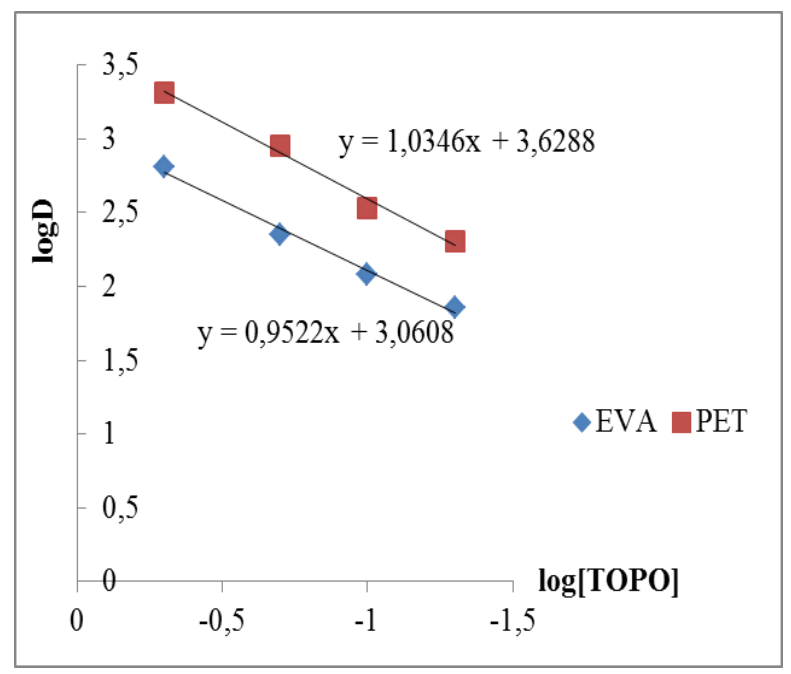

Figure 6. Variation of $\log D=f(\log [\overline{T O P O}])$

\section{Conclusion}

This study showed that the selected polymers, with the form of beads, can be used as support of solvent extraction. The best yields of extraction of copper ions alone are of the order of 80-99\%, in the presence of zinc, the yields are much improved. The best concentration factors of copper were 92287 times. They were not affected by the presence of zinc ions. This presents an interesting possibility for the concentration of metals from a mixture of several metal species.

Experimental data of extraction and formation of complexes, between copper and the carrier TOPO, are well described by a first order mode kinetic $\left(\mathrm{R}^{2}\right.$ $>96 \%$ ).

The relationship between $\log \mathrm{D}$ and $\log$ [TOPO] suggested the stoichiometry of the extracted species was 1:1 complex, namely, $\overline{\left[\mathrm{Cu}\left(\mathrm{NO}_{3}\right)_{2}\right] \mathrm{TOPO}}$.

The obtained results established that EVA, PVC and PET/TOPO/solvent extraction systems have potential for practical application in the metals and organic compounds removal and recovery.

\section{References}

[1] N. Taoualit, D. E. Hadj-Boussaad. Metallic species $\left(\mathrm{Ag}^{+}\right.$and $\left.\mathrm{Cu}^{2+}\right)$ transfert through a membrane-gel, Desalination 144 (2002) 273-277. DOI: 10.1016/S0011-9164(02)00327-2

[2] N. Taoualit, D.E. Hadj-Boussaad. Transport of silver metal ions through a liquid membrane gel using a solvating extractant (TOPO). Desalination 193 (2006), 321-326. DOI:10.1016/j.desal.2005.08.025

[3] E.H. Rifi, Extraction métallique par des gels hydrophobes, Doctoral thesis, Louis Pasteur University, Strasbourg, France, 1988.

[4] Organisation mondiale de la santé. Traces elements in human nutrition; a report of a WHO Expert Committee. WHO Technical Report Series 532, Genève. P. 70 (1973).

[5] G. Leóna, M. A. Guzmánb. Facilitated transport of copper through bulk liquid membranes containing different carriers: compared kinetic study, Desalination $223 \quad$ (2008) 330-336. DOI:10.1016/j.desal.2007.01.216

[6] Association Toxicologie-Chimie MDA 10206 quai de Valmy, 75010 paris http://atctoxicologie.free.fr

[7] M. Kermiche, S. Djerad. Facilitated transport of copper through bulk liquid membrane containing di-2ethylhexyl phosphoric acid, Desalination and Water Treatment 36 (1-3) (2011) 261-269.

[8] F.J. Alguacil, M. Alonso. Transport of $\mathrm{Au}(\mathrm{CN})_{2}{ }^{-}$ across a supported liquid membrane using mixtures of amine Primene JMT and phosphine oxide Cyanex 923 Hydrometallurgy, Volume 74, Issues $1-2 \quad$ (2004) 157-163. DOI:10.1016/j.hydromet.2004.03.001 
[9] D.K. Hale. National Research Development Corp., British Patent (Oct. 12, 1955) Br. 738, 500.

[10] H. Small. The Dow Chemical Company, U.S Patent, 3, 102, 782 (Sept. 3, 1963).

[11] A.N. Zelikman, L.V. Myakisheva, L.A. L'Nskaya, E.A. Baibekova, Yu.F. Korovin and V.K. Myasnikov. Tsvent. Met. (Moscow), 3 (1990) 7478.

[12] K. Shakir, M. Aziz and S.G. Beheir. Hydrometallurgy 31 (1-2) (1992) 41-54.

[13] T. Braun and A.B. Farag. Talanta 22 (1975) 699.

[14] S. Torok, T. Braun, P. Van Dyck and R. Van Grieken. X-Ray Spectrometry 15 (1986) 7.

[15] T. Braun and A.B. Farag. Anal. Chem. Acta 76 1975) 107.

[16] T. Braun and S. Palagyi. Anal. Chem. 51 (1979) 1697.

[17] T. Braun and M.N. Abbas. Anal. Chim. Acta 131 (1981) 311.

[18] M.N. Abbas, A. Vertes and T. Braun. Radiochem. Radioanal. Letters, 54, 17 (1982).

[19] T. Braun and M.N. Abbas. Anal. Chim. Acta 160 (1984) 277.

[20] H.D. Gesser, and S. Ahmed. J. Radioanal. Nucl. Chem. 140 (2) (1990) 395-408.

[21] A. Bachai, H.J.M. Bowen. Analyst 101 (1976) 661.

[22] N. Taoualit, I. Abidet, and D.E. Hadj-Boussaad. Extraction of copper and zinc by liquid-membranegel. Matec web of conferences 301065 (2013). DOI: $10.1051 /$ matecconf $/ 20130301065$

[23] T. Yano, S. Ide, Y. Tobeta, Kobayachi, Ueno H., K. Talanta 23 (1975) 457.

[24] DE. A. K Kouphar, S.M, Chalmers R.A, Solvent extraction of metals», Van Nostand Reinhold company (1970).

[25] L. Hatinger. Guide d'analyse des eaux de traitements de rejets de traitements de surfaces, CETIM (1990).

[26] N. Taoualit. Contribution à l'étude de l'extraction liquide-gel de l'argent. Masters Thesis, University of Blida, Algeria, 1999.

[27] C. Zidi, R. Tayeb, M. Dhahbi. Comparison between facilitated transport through a Supported Liquid Membrane (SLM) of phenol and vanillin extracted from aqueous solutions. J. Mater. Environ. Sci. 5 (3) (2014) 779-782.

[28] I. Ait-Khaldoune. Optimisation du transport des cations $\mathrm{Cu}(\mathrm{II}), \mathrm{Zn}(\mathrm{II})$ et $\mathrm{Cd}(\mathrm{II})$ par le tri-nbutylphosphate (TBP) à travers les membranes d'affinité. Magister thesis, of Tizi-Ouzou University, Algérie 2011,

[29] X. Yang, H. Duan, D. Shi, R. Yang, S. Wang, H. Guo. Facilitated transport of phenol through supported liquid membrane containing bis(2ethylhexyl) sulfoxide (BESO) as the carrier. Chemical Engineering and Processing 93 (2015) 79-86. DOI: 10.1016/j.cep. 2015.05.003

[30] X. Yang, A. Zou, J. Qiu, S. Wang and H. Guo. Phenol Removal from Aqueous System by Bis(2ethylhexyl) Sulfoxide Extraction. Separation Science and Technology Volume 49 (2014) - Issue 16. DOI: $10.1080 / 01496395.2014 .937497$ 